NBER WORKING PAPER SERIES

\title{
COULD STABLE MONEY HAVE AVERTED THE GREAT CONTRACTION?
}

\author{
Michael D. Bordo \\ Ehsan U. Choudhri \\ Anna J. Schwartz
}

Working Paper No. 4481

\author{
NATIONAL BUREAU OF ECONOMIC RESEARCH \\ 1050 Massachusetts Avenue \\ Cambridge, MA 02138 \\ October, 1993
}

This paper is part of NBER's research program in Monetary Economics. Any opinions expressed are those of the authors and not those of the National Bureau of Economic Research. 
NBER Working Paper \#4481

October 1993

\title{
COULD STABLE MONEY HAVE AVERTED THE GREAT CONTRACTION?
}

\begin{abstract}
We test the hypothesis that the Great Contraction would have been attenuated had the Fed not allowed the money stock to decline. We do so by simulating a model that estimates separate relations for output and the price level and assumes that output and price dynamics are not especially sensitive to policy changes. The simulations include a strong and a weak form of Friedman's constant money growth rule. The results support the hypothesis that the Great Contraction would have been mitigated and shortened had the Fed followed a constant money growth rule.
\end{abstract}

Michael D. Bordo

Department of Economics

Rutgers University

New Brunswick, N.J. 08903

and NBER

Anna J. Schwartz

National Bureau of Economic Research

269 Mercer Street, 8th Floor

New York, N.Y. 10003
Ehsan U. Choudhri

Department of Economics

Carleton University

Ottawa, Ontario

Canada K1S 5B6 


\section{Introduction}

Although over fifty years have elapsed since the onset of the Great Contraction, controversy still swirls about the factora responsible for its depth and long duration. A basic issue is the validity of the hypothesis due to Friedman and Schwartz (1963) that the Great contraction would have been attenuated had the Fed not allowed the money stock to decline. This issue has not been settled by the continuing debate on what mechanism accounts for the severity of the Great contraction.

The debate about the mecharism does not settle the igsue because each of the competing explanations is compatible with the Friedman-Schwartz hypothesis. For example, the debt-deflation explanation due to Fisher (1933) and recently extended and formalized by Bernanke and Gertler (1989, 1990) posits a large unanticipated fall in prices that has the effect of significantly reducing borrowers' net worth and thus beriously disrupting the process of financial intermediation. Whether price changes during the Great Contraction were in fact unanticipated, however, is the subject of dispute. Hamilton (1987, 1992) based on evidence from commodity futures markets and Evans and Wachtel (1991) from nominal interest rates find that the 1930-32 deflation was largely unanticipated. On the other hand, Nelson (1992) based on the business press and Cecchetti (1992) on time-series models of prices support the contrary view that the deflation was largely anticipated. For the latter, an explanation of the deepening of the Great Contraction related to high ex ante real interest rates is more relevant than the debt-deflation explanation.

Yet both of these explanations are compatible with the Friedman and Schwartz hypothesis in that stable money could have prevented a major deflation regardless of whether it was anticipated or not. The same conclusion follows from other explanations of the Great Contraction. Cecchetti and Karras (1992) use an econometric procedure to identify output declines up to the middie of 1931 as generally accounted for by demand shocks and subsequent output declines as mostly supply shocks. They treat the banking panics during the Great Contraction as supply shocks. Regardless of the source and 
importance of supply shocks, these results are not inconsistent with the Friedman and schwartz hypothesis since a stable money policy could have diminished the effect of all types of shocks to the economy.

A direct test of the Friedman and Schwartz hypothesis requires simulating the behavior of output under a counterfactual policy of stable money. That approach was adopted in the past by warburton (1966), Friedman (1960), and Modigliani (1969), none of whom constxucted a model of the economy on the basis of which to conduct his test. The problem with simulations, whether or not based on a model, is that they are subject to the Lucas critique (1976): with a shift in regime from an unstable to a stable money policy, the parameters describing the economy could change.

such a problem, however, may not be too serious at least for ceztain relationships. For example, assuming that the relationship between money and nominal income is robust with respect to regime changes, McCallum (1990) uses simulations from a macro model to show that his base rule (with feedback) would have avoided the decline in nominal income that occurred between 1929 and 1933.' We use an approach similar to McCallum's except that we focus on different sets of rules, and we estimate separate relations for output and the price level. Our stable-money counterfactual does not change the long-term rate of money growth (from that actually experienced) and thus involves oniy short-run changes in the behavior of the money supply. We assume that dynamics embedded in the output and price relation are not especially sensitive to this type of policy change.

In this paper we simulate two variants of Milton Friedman's (1960) constant money growth rule. The first, a strong form of the rule assumes that the Fed could quickly offset changes in the money multiplier by changes in high-powered money and thus keep the money stock on the constant growth rate path in each quarter. The second, a weaker form of the rule, assumes that the money multiplier is observed with a one-quarter lag and the Fed can only set the expected rate of growth of money (conditional on last period information) equal to the constant rate. ${ }^{2}$ our basic simulation is based on a model 
estimated for the 1921.1-1941.4 interwar period. The results of this simulation buttress the views of Friedman and schwartz. Had a congtant money growth rule (with an annual rate equal to the average 1921-41 rate of 2.95\%) been followed throughout the interwar period the Great contraction would have been avoided. Real output would have declined from 1929.3 to 1933.1 , but the order of magnitude of the annual rate of change ( -3.3 to -6.6 percent), when the actual annual rate of change was -12.1 percent, would have been comparable to other recessions in the nineteenth and twentieth centuries. The extraozdinary economic conditions of the Great contraction could have arguably shifted the output and price reiations. Thug, we also implement an alternative simulation that uses estimates of these relationg based on the 1920's data. This simulation shows that a constant money growth rule (with an annual rate equal to the 1921-29 average of 3.298 ) would have prevented even a mild recession during the Great contraction period.

Our simuiations also have implications for issues recently raised by Romer (1992). Romer wishes to explain the determinants of the recovery from 1933 to 1941. Based on money income multipliers calculated for the years 1921 and 1938 she simulates the behavior of real output from 1933 to 1941 if money growth had not deviated from the average (MI) money growth rate of 1923 to 1927 of 2.88 percent. Such a money growth rate would have led to a 50 percent gap below potential output in 1941 . The fact that actual output grew substantially faster makes her case that gold-flow-induced expansionary money supply produced the recovery. Our simulation also covers the recovery period 1933 to 1941 but unlike Romer, who assumed that the money supply collapsed from 1929 to 1933, as it did, our simulation assumes that a constant money growth rule for $M 2$ was maintained over the entire interwar period. Our simulations suggest that the extra monetary stimulus Romer documents would have been unnecessary had stable money been followed throughout the interwar period.

Section 2 presents an overview of the behavior of the variables considered in our model. Section 3 describes our methodology for performing 
counterfactual simulations for the interwar years 1921 to 1941 . Section 4 provides basic simulations of the paths of output and the price level under different variants of the constant money growth rule. section 5 explores the sensitivity of our results to alternative specifications. Section 6 contains a brief conclusion.

\section{Output, Prices, and Money in the Interwar Years}

Before discusging our model, we briefly review the behavior of real output, the price level, and the money supply during the interwar period. For the data definitions and sources, see Appendix I.

Figure la shows quarterly time series of the log of real GNP (Y) for the period 2921.1 - 1941.4. Output grew from 1921.1 to the cyclical peak in 1929.3 at an annual rate of 6.4 percent. The period was marked by two mild recessions: 1923.2 to 1924.3 and 1926.3 to 1927.4 . Output then declined from 1929.3 to the cyclical trough in 1933.1 by 36.2 percent (at an annual rate of -12.1 percent), the sharpest and most prolonged decline in U.S. history. Rapid recovery then followed until the outbreak of World war II, with output growing at the annual rate of 8.6 percent. Recovery was marred by a brief, sharp recession 1937.2 to $1938.2 .^{3}$

Figure ib presents the quarterly data for the log of the implicit GNP deflator (p) for the interwar period. Following a sharp post-World War I deflation, the price level was mildiy deflationary until the summer of 1929 when it began a rapid plunge for the next three and a half years. It declined by 26.8 percent, or an annual rate of -8.5 percent. The deflation of $1929-$ 1933 was the most severe in U.S. history. Unanticipated deflation because of deleterious effects on the balance sheets of households and firms has been viewed by Fisher (1933) and Bernanke (1983) as an aggravating force in the Great contraction. From the cyclical trough in 1933.1 until World War II prices advanced at an annual rate of 3.5 percent except for a deflationary episode from 1937.3 to 1939.2 . 
Figure 1

a) The Logarithm of GNP in 1972 Prices, Quarterly Data, 1921:1 to 1941:4

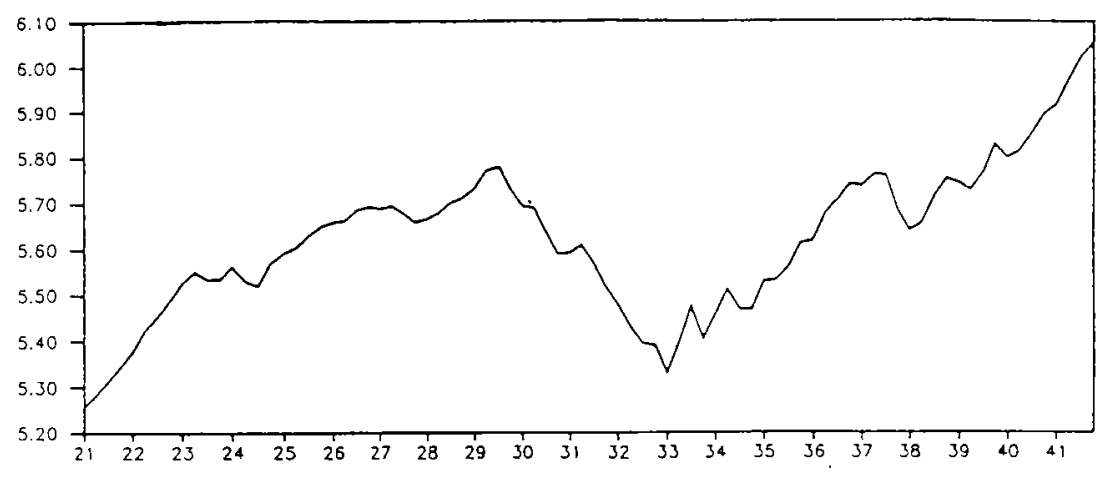

b) The Logarithm of the GNP Deflator $(1972=100), 1921: 1$ to $1941: 4$

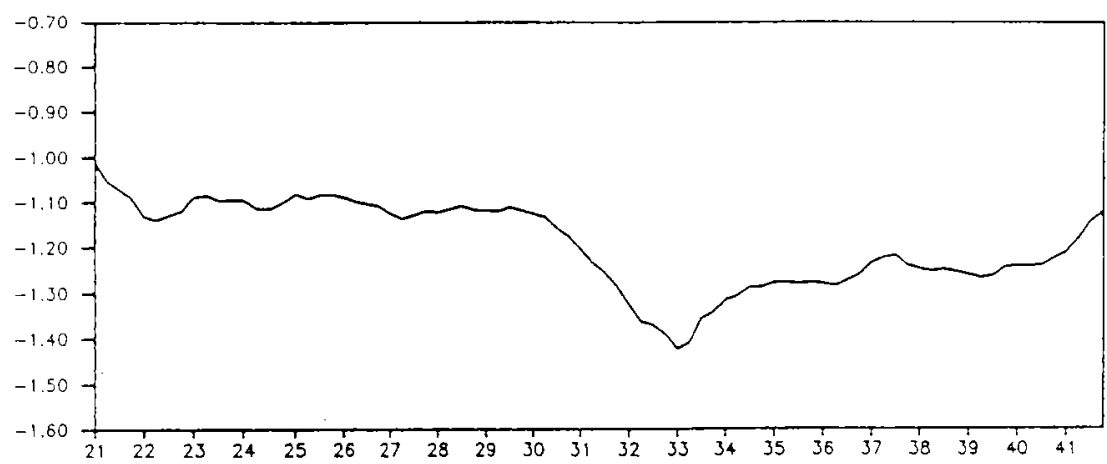

c) The Logarithm of the M2 Money Stock, 1921:1 to 1941:4

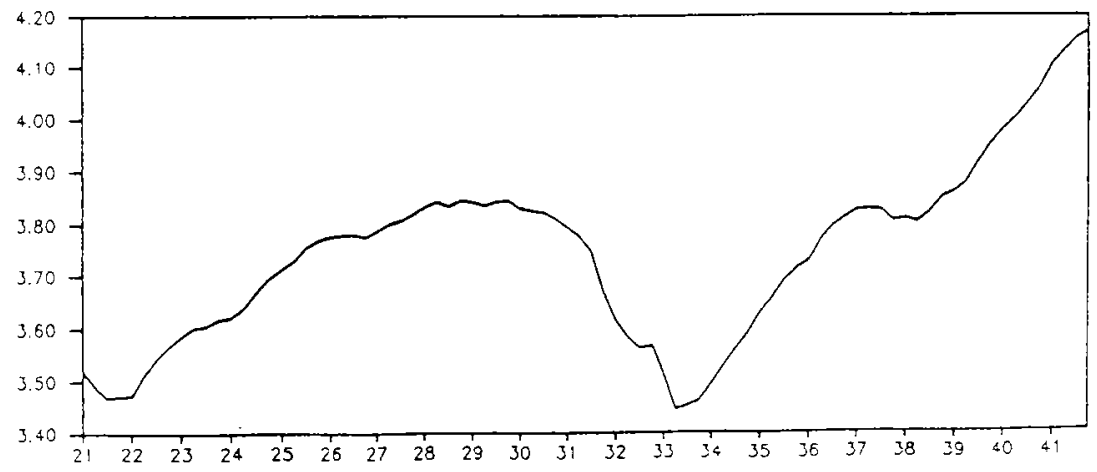


Figure lc displays the behavior of the $\log$ of the M2 money supply $(\pi) .{ }^{4}$ Following a sharp policy induced contraction after world war I, the money supply increased from 1922.2 until 1928.2 at an annual rate of 5.7 percent. The subsequent failure to grow in 1928-29 reflected contractionary Federal Reserve policy in reaction to the atock market boom and a gold flow to France after it returned to the gold standard at a parity that undervalued the franc (Hamilton 1987, Field 1984). Money supply declined for the first year of the Great Contraction by 2.2 percent, a decline not much different from that experienced in earlier severe recessions (Friedman and Schwartz 1963)," but beginning in October 1930, with the onset of a series of banking panics it began a plunge whereby $M$ fell by 12.4 percent at an annual rate. The fall in $M$ did not end until the Banking Holiday of March 1933.

Beginning in March 1933, the money supply expanded rapidiy at an annual rate of 7.8 percent until world war II, with the exception of a sharp contraction in 1937-38. According to Friedman and schwartz, the Federal Reserve decision to double reserve requirements in an attempt to soak up what it regarded as excess liquidity in the banking system was responsible for the monetary contraction.

Friedman and Schwartz attribute the severe decline of the money supply from 1930 to 1933 to a series of banking panics which ultimately caused onethird of the nation's banks to fail. The banking panics reduced the money supply by their effects on the money supply multiplier (see figure 2a). The bank failures, attributed to the absence of Federal Reserve lender of last resort action, undermined the public's confidence, leading to a massive decline in the deposit-currency ratio. The banks in turn reduced their loans, resulting in a sharp fall in the deposit-reserve ratio (see figure $2 \mathrm{~b}$ ).

In contrast to Friedman and schwartz who attach importance to the bank failures as the force which led to a collapse of the money supply, for Bernanke (1983) they were also important for their nonmonetary role of impairing the financial intermediation process and hence reducing the level and growth rate of real output. ${ }^{\circ}$ As a standardized measure of the importance 
Figure 2:

a) The Logarithm of the Money Multiplier (M2/Base), 1921:1 to 1941:4

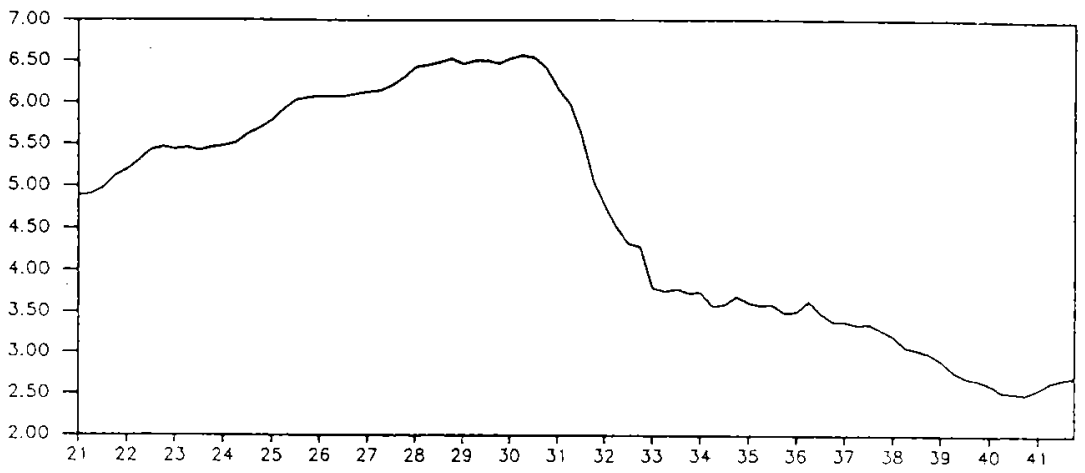

b) The Logarithm of the Deposit Currency and Deposit Reserve Ratios

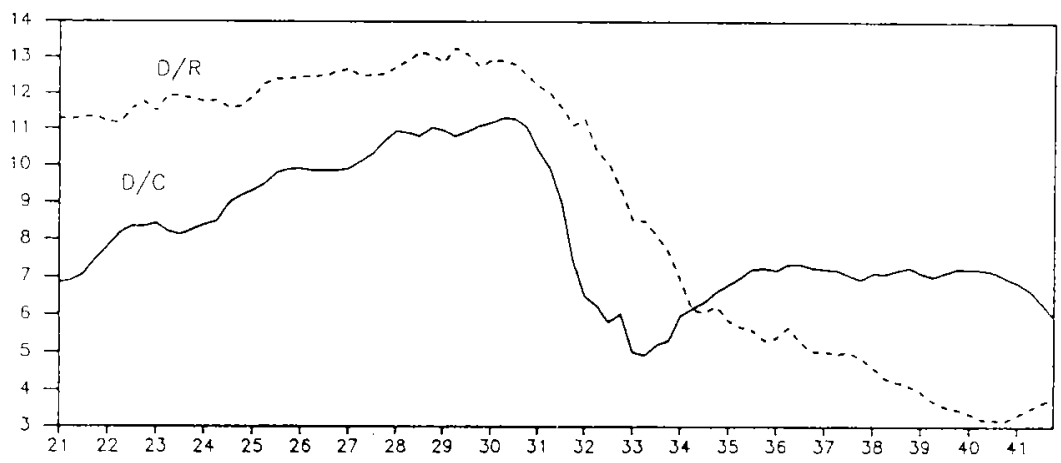

c) The Logarithm of Real Deposits in Suspended Banks

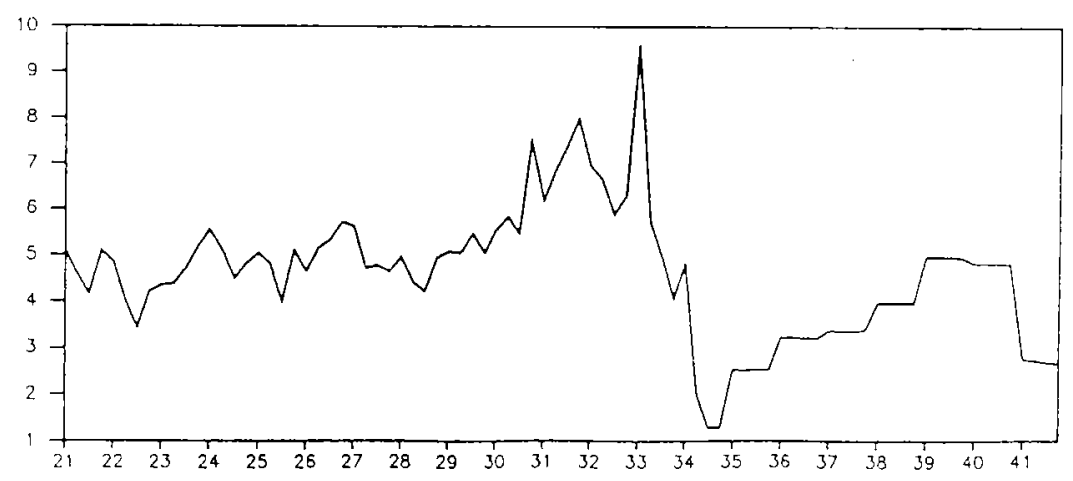


of bank failures, we use the $\mathrm{log}$ of the ratio of depositg in suspended banks to total deposits (s) (see figure 2c)..$^{7}$ was guite high in the $2920^{\prime} \mathbf{s}$, reflecting deep-seated structural problems in the U.S. banking system -- the weakness of unit banks in primarily agricultural areas of the country. The dramatic increase in 9 from 1930-33 largely reflects the banking panics. Following the Bank Holiday of March 1933 and the advent of FDIC in 1934, 3 declined to a much lower level." That the rise in 5 1930-33 was accompanied by a fall in the money supply multiplier underscores the importance of bank failures in the money supply process.

\section{Methodology}

In this section we describe the methodology we use to perform counterfactual historical simulations for the interwar period. We estimate a small quarterly model of the interwar U.S. economy. To keep our framework simple, our basic model includes only 3 variables, $y, p$ and $m$. However, we also consider two variations of the basic model. In one variation, we introduce the rate of interest (r) as an additionai variable while in the other we add the variable s to captuxe the role of bank failures. We assume that money affects output in the short run. The short-run nonneutrality of money is assumed to result from sticky prices or wages."

We assume that $y, p, m, r$, and $s$ are all stationary in first differences. 10 Also, we assume initially that the first four of these variables are cointegrated via a money demand relation of the following form:

$$
m_{t}-p_{1}=\alpha_{0}+\alpha_{1} y_{t}+\alpha_{2} r_{1}+v_{1}
$$

where $v_{1}$ is a stationary component. ${ }^{11}$ In view of (1), we include $v_{1-1}$ as an error correction term in the equations that model the behavior of output and the price level as follows:

$$
\Delta y_{1}=\beta_{10}+\beta_{11} v_{t-1}+a_{11}(L) \Delta y_{t-1}+a_{12}(L) \Delta p_{t}+a_{13}(L) \Delta m_{t}+a_{14}(L) \Delta z_{1}+\delta_{11} \eta_{1}^{d}+\delta_{12} \eta_{1}^{\prime},
$$




$$
\Delta p_{1}=\beta_{20}+\beta_{21} v_{t-1}+a_{2}(L) \Delta p_{t-1}+a_{21}(L) \Delta y_{1}+a_{22}(L) \Delta m_{1}+a_{24}(L) \Delta z_{1}+\delta_{21} \eta_{1}^{\prime}+\delta_{22} \eta_{1}^{\prime},
$$

where $a_{i j}(L)$ are lag polynomials of order $k, z_{1}=r_{1}$ or $s_{1}$, and $\eta_{1}^{d}$ and $\eta_{1}^{\prime}$ are mutualiy uncorrelated white-noise disturbances representing demand and supply shocks respectively. ${ }^{12}$ The determination of the money supply is modeled as

$$
\Delta m_{1}=\beta_{30}+a_{33}(L) \Delta m_{1-1}+a_{31}(L) \Delta y_{1}+a_{32}(L) \Delta p_{1}+a_{3}(L) \Delta z_{1}+\eta_{1}^{m},
$$

where $\eta_{1}^{m}$ is a white-noise money supply shock (uncorrelated with both $\eta_{1}^{d}$ and $\left.\eta_{i}\right)$. Equation (4) allows for potential effects of $y, p$ and $z$ on $m$ through high-powered money (via the Fed's reaction function) as well as the money multiplier.

In our basic model, we suppress the role of both $I$ and $s$ by letting $\alpha_{2}=0$ in (1), and $\alpha_{i 4}(L)=0, i=1,2,3$, in (2)-(4). Friedman and schwartz (1963) treated bank panics as exogenous shocks to money supply and did not consider output and the price level as significant determinants of either the high powered money or the money multiplier. Their view suggests including bank panic shocks in $\eta_{1}^{m}$ and setting $a_{31}(L)=a_{32}(I)=0$ in (4).

We estimate our basic model in the form of a vector error correction model. Letting $x_{1}=\left[\Delta y_{1}, \Delta p_{1}, \Delta m_{1}\right]$ and $\eta_{1}=\left[\eta_{1}^{d}, \eta_{1}^{2}, \eta_{1}^{\mathrm{m}}\right]$, write $(2)-(4)$ as $\mathrm{Ax},=\beta_{0}+\beta_{1} \mathrm{~V}_{\mathrm{t}-1}+\mathrm{B}(\mathrm{L}) \mathrm{x}_{\mathrm{t}-1}+\delta \eta_{1}$, and premultiply by $\mathrm{A}^{-1}$ to obtain

$$
x_{t}=\gamma_{0}+\gamma_{1} v_{t-1}+C(L) x_{r-1}+e_{t},
$$

where $y_{i}=A^{-1} \beta_{i}, i=0,1, C(L)=A^{-1} B(L)$ and $e_{1}=\left[e_{1}^{y}, e_{1}^{p}, e_{1}^{m}\right]$ is vector of reduced form shocks. The reduced form shocks are related to structural shocks by

$$
e_{1}=D \eta_{1},
$$


where $D\left(=A^{-1} \delta\right)=\left[D_{i j}\right], i, j=1,2,3$.

To perform counterfactual gimulations of $y$ and $p$ based on (5), we define the congtant money growth (CMG) policy as the Fed targeting a rate of growth of the money stock equal to $\theta$, based on all available information. Under this policy

$$
E\left(m_{r} \mid I_{1}\right)=m_{i-1}+\theta,
$$

where $I_{1}$ is the Fed's information set in period $t$. The degree of monetary control under CMG clearly depends on the information available to the Fed. We consider several possibilities. At a minimum, we assume that the Fed observes all variables with a one period lag (i.e., $I_{1}$ contains value of all variables up to $t-1$ ). Using this weak informational assumption, cMg rule (7) implies that the $\Delta m$ equation of model (5) will change to

$$
\Delta m_{1}=\theta+e_{i}^{m} \text {. }
$$

We replace the Am equation in (5) by (8) to simulate the behavior of $y$ and $p$ under this policy. This simulation does not require identification of structural shocks.

A stronger assumption about the Fed's monetary control is that it knows contemporaneous money supply shocks (i.e., $I_{1}$ includes $\eta_{\mathrm{l}}^{\mathrm{m}}$ in addition to information on all variables up to t-1). In this case the CMG policy would

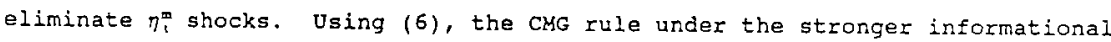
assumption implies that

$$
\Delta m_{1}=\theta+e_{1}^{m=}
$$

where $e_{1}^{m^{*}}=D_{31} \eta_{1}^{d}+D_{32} \eta_{1}^{\prime}$. Moreover, with money supply shocks eliminated, $\Delta y$ and $\Delta p$ equations in (5) will be subject only to shocks $e_{1}^{y=}=D_{11} \eta_{1}^{d}+D_{12} \eta_{1}^{*}$, and 
$e_{1}^{p^{*}}=D_{21} \eta_{1}^{d}+D_{2} \eta_{1}^{d}$ respectively. Note that the simulation based on (9)

requires the identification of only $\eta_{1}^{m}$ shocks as $e_{i}^{*}$ can be estimated as a residual in a projection of $e_{i}^{*}$ on $\eta_{1}^{m}, w=y, p, m$.

A number of approaches can be used to identify $\eta_{1}$. One interesting posaibility is suggested by the friedman-schwartz view that the behavior of m was essentially independent of $y$ and $p$. If it is assumed that $y$ and $p$ do not affect $m$ at least contemporaneously, then $a_{31}(0)=a_{32}(0)=0$, and these exclusion restrictions imply that $D_{31}=D_{32}=0$ while $D_{33}=1$. Thus $e_{1}^{\mathrm{m}}=\eta_{1}^{\mathrm{m}}$, and (since $e_{1}^{m^{*}}=0$ ) the counterfactual money supply equation (9) reduces to

$$
\Delta m_{i}=\theta
$$

As (8) and (10) represent polar assumptions about monetary control, the next section focuses on simulations based on these equations to present the least and the most favourable cases for stable money.

As extentions of our basic model, we include a fourth variable $z$ representing either $r$ or $s$. The behavior of the fourth variable is modeled as

$$
\Delta z_{1}=\beta_{40}+a_{41}(L) \Delta z_{1-1}+a_{41}(L) \Delta y_{1}+a_{42}(L) \Delta p_{1}+a_{43}(L) \Delta m_{1}+\eta_{1}^{2},
$$

where $\eta_{1}^{2}$ is assumed to be white noise and uncorrelated with other shocks. In the case of $z_{1}=r_{1}, \eta_{1}^{x}$ can be viewed as shocks to asset markets while for $z_{1}=s_{1}, \eta_{1}^{2}$ can be thought of as financial shocks relevant to bank suspensions and failures. The model represented by (1), (2), (3), (4) and (11) (with $\alpha_{2}=0$ in (1) for $z_{1}=s_{1}$ ) can be estimated in the form of (5) with $x_{1}$ and $e_{1}$ redefined as $\left[\Delta y_{1}, \Delta p_{1}, \Delta m_{1}, \Delta z_{1}\right]$ and $\left[e_{1}^{y}, e_{1}^{p}, e_{1}^{m}, e_{1}^{x}\right]$. In this case, however, the restriction that $y$ and $p$ do not contemporaneously affect $m$ is not sufficient to identify $\eta_{1}^{m}$ since $z$ could still exert a contemporaneous effect on $m$. While identification of $\eta_{1}^{m}$ is not needed for counterfactual (8), additional assumptions would be required to justify counterfactual (10). 
Our simulations assume that a change in the $\Delta m$ equation does not alter other equations of the model. We suppose that the short-run adjustment process is not very sensitive to a change in monetary policy. The long-run rate of inflation would, however, depend on the long-run rate of money growth. Thus, in constructing our counterfactual, we avoid a change in the long-run money growth rate by setting $\theta$ equal to the average value of $\Delta \mathrm{m}$ for the period over which our model is estimated.

Our model does not explicitly constrain money to be neutral in the long run. One implication of long-run neutrality of money is that $\eta^{\text {m would not }}$ permanently affect $y$. This restriction poses no problem for simulations based on (8) as any set of restrictiong used to identify structural shocks would be consistent with this counterfactual. However, restrictions used to identify $\eta_{1}^{m}$ for counterfactual (10) would not constrain the long-run effect of this shock to equal zero.

\section{Basic Simulations}

Before discussing our simulations, we present some evidence on the relationship between money and other variables in the model in the interwar period. Table 1 shows results of Granger causality tests between certain variables in the model for 1921.1-1941.4. Regressions in this table include the lagged value of the error correction term, $v$, and 3 lagged values of other regressors. Here, assuming that $\alpha_{1}$ equals one and $\alpha_{2}$ equals zero, we measure $v$ by $(m-p-y) \cdot \cdot^{13}$

The first three regressions in the table are based on the 3-variable framework of the basic model. In the first regression, we examine the influence of output and the price level on money. As the results show 3 lagged values of both $\Delta y$ and $\Delta p$ as well as the lagged value of $v$ are insignificant in the regression explaining $\Delta m$. This evidence on the absence of Granger causality from $y$ and $p$ to $\mathrm{m}$ is consistent with the view that money supply in this period was exogenous. The second and the third regressions in 
the table examine the links from money to output and the price level. The lagged values of $\Delta m$ are significant (at the .011 level) in the $\Delta y$ equation but insignificant in the $\Delta p$ equation. However, even in the $\Delta p$ equation, the lagged value of $v$ is significant (at the .023 level), and thus money does exert an effect on the price level through the error correction term. Although we have suppressed the role of the interest rate in our basic model, we nevertheless explore the influence of this variable on money, output and the price level in regressions 4,5 and 6 . As the results show, interest rates do not improve the predictive content of any of these regressions.

The remaining regressions in the table explore the interaction of $s$ with m, $p$ and $y$. The results based on regressions $7-9$ show that lagged $\Delta s$ terms are significant in the $\Delta m$ and $\Delta$ p equations (at .017 and .060 levels, respectively) but not in the $\Delta y$ equation. In regression 10 , on the other hand, lagged values of both $\Delta p$ and $\Delta m$ are significant (at .015 and .052 levels) in the $\Delta s$ equation. These results suggest a role for $s$ in the model but note that the effects operating between $s$ and other variables are not very strong. For example, inclusion of this variable in the $\Delta \mathrm{m}$ and $\Delta \mathrm{p}$ equations increases the $\bar{R}^{2}$ of these equations only marginally by .043 and .027 , respectively (compare regression 7 with 1 , and 9 with 3 ). The $\bar{R}^{2}$ of the $\Delta s$ equation, moreover, is only . 160 .

We begin with simulations based on the basic vector error correction model (5) with 3 variables. We estimate this model using 3 lags for each variable. ${ }^{14}$ Although our interest is primarily in the Great contraction period, we simulate the behavior of $\Delta Y$ and $\Delta P$ under the CMG policy for the whole interwar period. We focus on the two variants of the CMG policy discussed above. The weak case for this policy is represented by Model I defined as model (5) with its $\Delta$ m equation replaced by ( 8 ). Model II, on the other hand, represents the strong case. This model is defined as model (5) in which not only is the $\Delta m$ equation replaced by (10) but also $e_{1}^{y}$ and $e_{1}^{p}$ in the $\Delta y$ 
and $\Delta p$ equations are replaced by $e_{l}^{p}$ and $e_{1}^{p *}$ lestimated as residuals in regressions of $e_{1}^{y}$ on $e_{1}^{m}$ and $e_{1}^{p}$ on $e_{1}^{m}$ ). In both models $I$ and II, $\theta$ is set equal to .00738 (the mean value of $\Delta m$ for $1921.1-1941.4$ )..$^{\text {is }}$

Figure 3 shows the simulated behavior of $\mathrm{m}, \mathrm{p}$, and $y$ for models $I$ and II, and compares it to the actual behavior of these variables. The actual and counterfactual monetary policies are contragted in panel (a) of the figure. Note that even the weaker CMG rule (uged in model I) would have resulted in only minor decreases in the money stock during 1931-33.

The basic question raised in this paper is addressed in panel (b) of figure 3. As this figure shows, a fall in $y$ would have occurred starting in 1929 in model I but the simulated decline ( -6.61 percent at an annul rate) would not have been as severe and prolonged ag the decline in the Great Depression ( -12.1 percent at an annual rate). In fact, under this counterfactual a recovery would have begun in 1933 and output would have reached its 1929 level by early 1934. The 1929-33 output decrease in this case would have represented a major but not an exceptional recession. Model I assumes that the CMG policy would not have had any influence on money supply shocks. However, if this policy had eliminated these shocks according to the identifying assumptions of model II, then as the model II simulations in figure 3 (b) show, output would have decilined only modestly $(-3.30$ percent at an annual rate) during 1929-31 and this episode would not have been considered a major recession. Interestingly, in both models CMG policy does not appreciably change output until 1931 which is consistent with Romer's (1990) position that the 1929-30 contraction was due to non-monetary forces -specifically, the stock market crash. It is also interesting to note that the simulated level of output in both models stays well above the actual level not only during the Great contraction period but also throughout the subsequent recovery period. Figure $3(c)$ shows that the behavior of the price level would also be significantly altered under both counterfactuals, but deflation still persists in both cases. 
Figure 3:

a) The Logarithm of M2 (m), Simulated and Actual

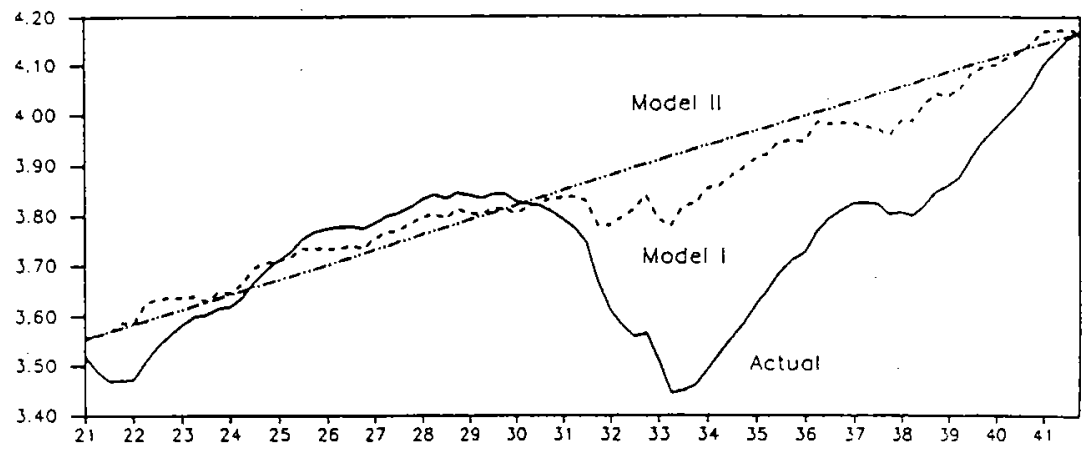

b) The Logarithm of Real GNP (y), Simulated and Actual

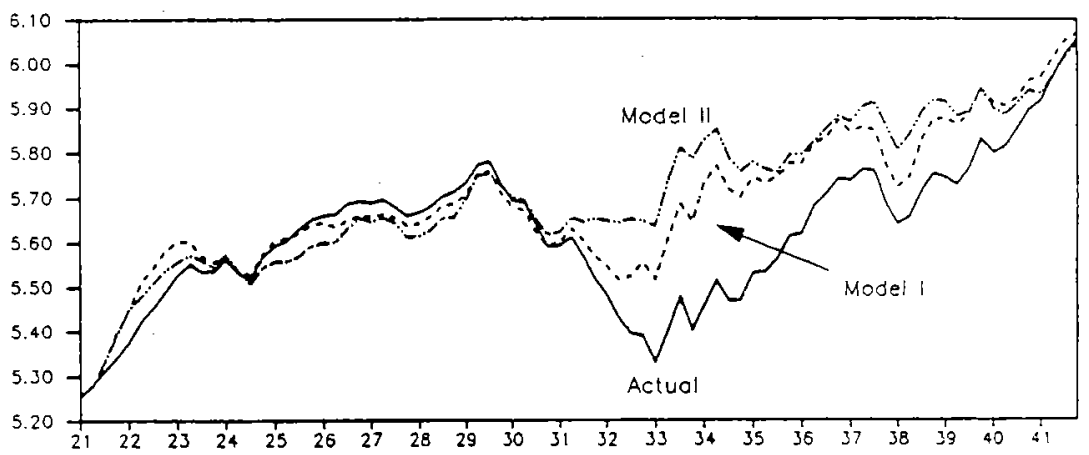

c) The Logarithm of the GNP-Deflator (p). Simulated and Actual

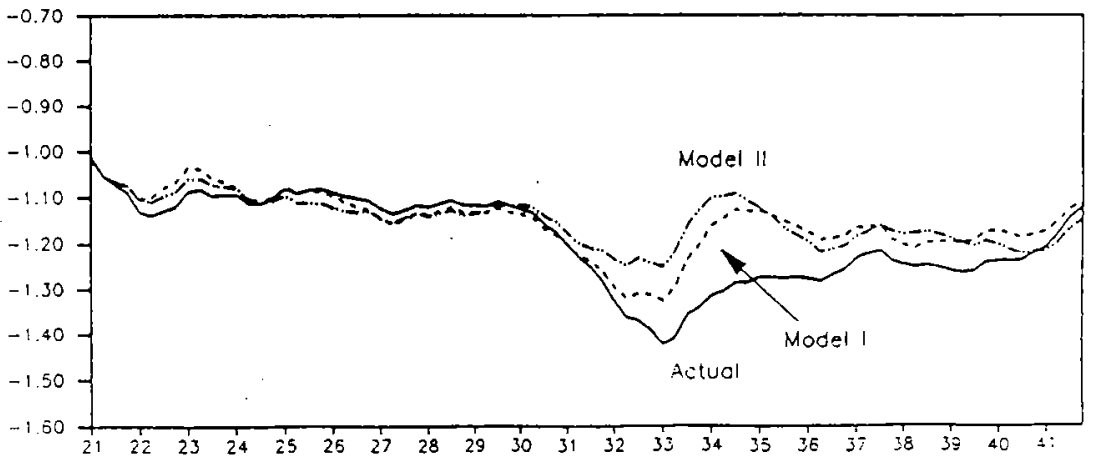


Table 2. Compared to model I, mean ( $\left.y^{*}-y\right)$ for model IA is lower by a small amount (.006) for the whole period but a somewhat larger amount (.010) during the Great contraction. Comparison of model II with IIA showg similar results. The performance of CMG policy thus deteriorates somewhat if the errorcorrection term is removed from the model.

Next, we extend our model to include $s$ or $r$ as an additional variable as discussed in section 3. For this case we consider only the simulations based on the weak counterfactual since the strong counterfactual would require additional assumptions to identify money supply shocks. The 4-variable vector error correction model under the weak monetary-control assumption is labelled model IB when the fourth variable represents $\mathrm{s}$ and model IC when it represents r. ${ }^{16}$ Measures of performance for these two models are also shown in Table 2. Model IB leads to a slightly higher level of output than Model I during the Great Contraction but the overall performance of thege two models is not much different. Thus the introduction of variable $\mathrm{s}$ does not make an appreciable difference to the results. The results change more significantly under model 1C. While this model produces greater variability of both output growth and inflation, it also brings about a higher level of output. On balance, its performance compares favourably to that of model I.

Our data on $y$ and $P$ are the Balke-Gordon quarterly series on real GNP and the GNP deflator. As these series use interpolations of annual data, they allow future information to influence current values. To explore whether this data problem may have introduced a serious bias in our results, we also estimated our basic model using quarterly averages of monthly data on industrial production and the wholesale price index as alternative measures of $y$ and $p$. The weak and strong versions of the basic model based on the alternative data set are labelled ID and IID. Measures of performance for these two models in Table 2 show that although the effect of the CMG policy on the variability of $\Delta y$ and $\Delta p$ differs between the two models, the policy substantially increases the level of output, especially during the Great Contraction, in both models. Indeed, in terms of the effect on the level of 
output, the case for the CMG policy is stronger if the data on industrial production and the wholesale price index are used instead of the Balke-Gordon estimater (compare model ID with I and IID with II).

Our simulations asgume, not only that a CMG policy would not have significantly altered the output and price equations but also that these equations were stable throughout the interwar period. We tested our model for possible breaks at three different dates, 1930.1, 1931.4 and 1933.2, which represent the beginning, the middle and the end of the Great contraction. The Chow test of a break at a fixed date indicates a shift in both the output and price equations in 1930.1 as well as in 2933.2. It may be thought that an equation explaining nominal income would have been more stable than our separate output and price equations. However, testing a comparable nominalincome equation for stability, a chow test indicates a break in this relation in 1933.2 , though not in 1930.1 .17

If, as the above evidence indicates, the Great contraction was responsible for shifts in the output and price relations, then these shifts would not have occurred under a CMG policy that prevented the contraction. This possibility suggests using relations estimated for the stable 1920's to construct the CMG counterfactual for the whole interwar period. For this simulation, the basic model was estimated separately for the subperiods 1921.1-1929.4 and 1930.1-1941.4 to calculate reduced-form shocks for the whole period. Then, using output and price equations estimated for the 1921.11929.4 subperiod and letting $\theta=.00822$ (the mean value of $\Delta \mathrm{m}$ for this subperiod), the behavior of $m, y$ and $p$ was simulated under both the weak and strong monetary control assumptions. These simulations are referred to as models IE and IIE, respectively, and are illustrated in figure 5.

As figure 5 shows, the behavior of $y$ and $p$ under both model IE and IIE is dramatically different from previous simulations. The most remarkable difference is in the behavior of $y$ which unlike previous cases does not exhibit any gignificant contraction during the 1929-33 period under both the weak and strong forms of the CMG rule. This result fully supports the 
Figure 5:

a) The Logarithm of $M 2(m)$, Simulated and Actual

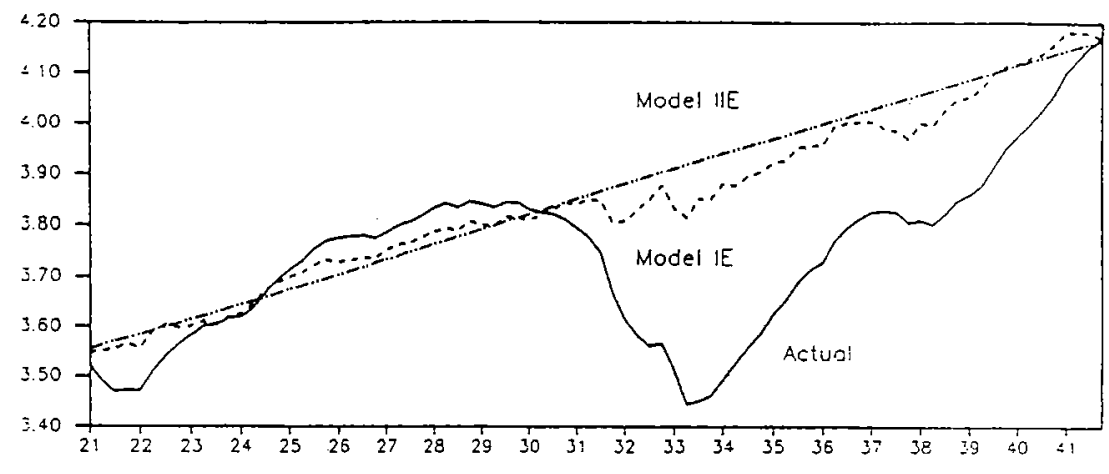

b) The Logarithm of Real GNP (y), Simulated and Actual

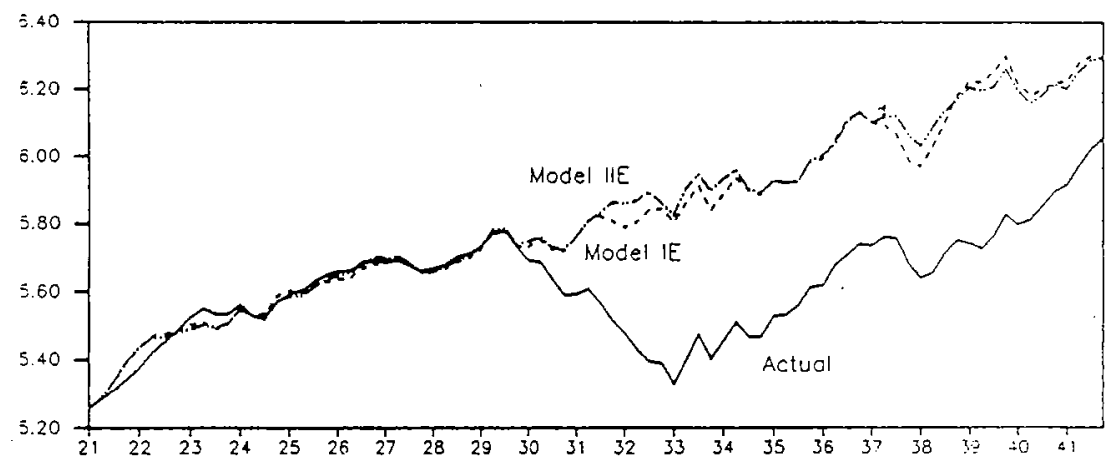

c) The Logarithm of the GNP-Deflator ( $p)$, Simulated and Actual

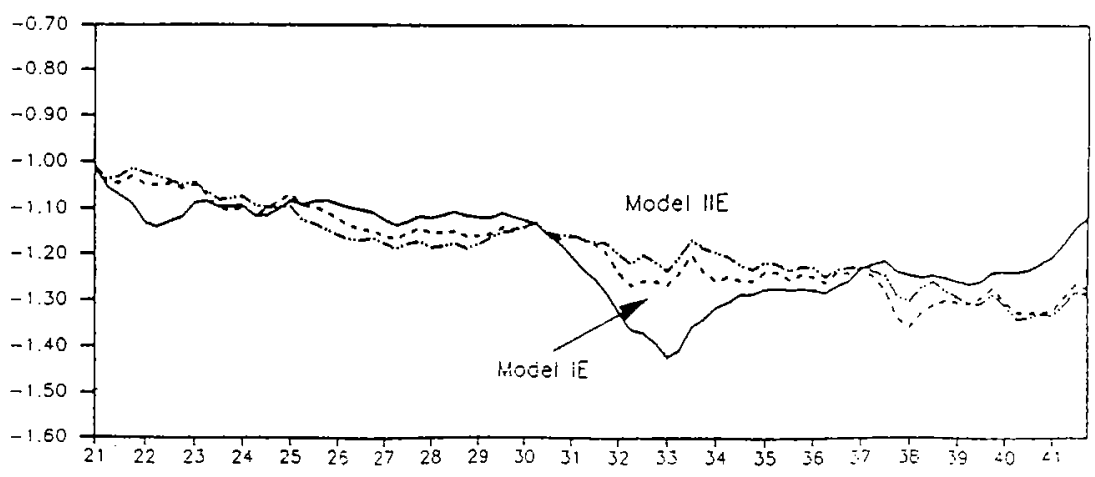


underlying assumption of the simulation that by preventing the Great Contraction, the CMG policy would have preserved the 1920's output and price relations. Performance measures for models IE and IIE in Table 2 show that although these models would have made a marginal difference to the variability of the price level, they would have produced a substantially higher level of output and a significantly lower output variability.

As noted above, the collapse of financial intermediation could have accounted for the result that money shocks had long-term effects on output in model II. If money is otherwise neutral in the long-run, we would not expect money shocks to exert a permanent effect on output in a model based on the period before the financial collapse. This prediction is supported by panel

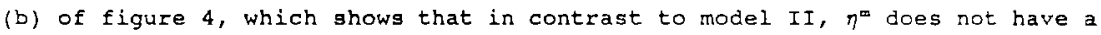
marked long-run effect on $y$ in model IIE.

\section{Conclusion}

This paper provides a novel approach to the long-debated question of whether stable money could have averted the Great contraction in the united states. Our basic model estimates separate relations for output and the price level, and assumes that output and price dynamics are not especially sensitive to policy changes.

Basic simulations of two variants of Milton Friedman's constant money growth rules produce results consistent with claims that, had a stable money policy been followed, the Great contraction would have been mitigated and shortened. A severe recession would have occurred but not of the extraordinary character of the Great contraction. If it is further assumed that a stable money policy would have prevented shifts in the output and price relations, our alternative simulations produce the much stronger result that there would have been no recession at all during the Great contraction under both variants of the CMG rule.

If our simulations are valid, then the extra monetary stimulus that Romer (1992) argues was necessary to produce recovery after 1933 would not 
have been essential. In fact, under all of our CMG counterfactuals, simulated output is well above the actual output throughout the 1933-41 period.

We say nothing about the views that the Great Contraction was spawned by world atructural imbalances (Temin 1989), or by the decline in U.S. foreign lending (Eichengreen 1992). However, those subscribing to these views would agree that the U.S. depression was the catalyst that created the worldwide debacle. Therefore, our conclusion that stable money would have made the U.S. decline less severe holds also for the world.

He limit our counterfactual to what would have happened under a constant money growth rule. We do not attempt counterfactual simulations for alternative rules: Mccallum's monetary base rule with feedback from the real economy; Feldstein and stock's (1992) activist-based rule; a gold standard or a commodity basket rule; or other variants of price rules.

It has been argued that, "After all, aside from the time consistency issue, there is little theoretical reason to recommend a ko rule" (Eichenbaum 1992). The view that ko rules (our CMG) is suboptimal compares economic performance under CMG with alternative rules or discretion that yields a superior outcome. Our focus, however, is on the CMG relative to actual performance during the Great Depression. On that basis, CMG was clearly preferable. 
Table 1 - Tests of Granger Causality

\begin{tabular}{|c|c|c|c|c|c|}
\hline \multicolumn{3}{|c|}{ Regresgions } & \multicolumn{3}{|c|}{ F-Tests } \\
\hline No. & $\begin{array}{l}\text { Dependent } \\
\text { Variable }\end{array}$ & $\begin{array}{c}\text { Regressors } \\
\text { (no. of lags) }\end{array}$ & $\overline{\mathrm{R}}^{2}$ & $\begin{array}{c}\text { Excluded } \\
\text { Variable(s) }\end{array}$ & $\begin{array}{c}\text { F-statiotic } \\
\text { (p-value) }\end{array}$ \\
\hline 1. & $\Delta \mathrm{m}$ & $\begin{array}{l}c, v(1), \Delta y(3), \\
\Delta p(3), \Delta m(3)\end{array}$ & .552 & $\begin{array}{l}\Delta y(3) \\
\Delta p(3) \\
v(1)\end{array}$ & 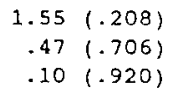 \\
\hline 2. & $\Delta y$ & $\begin{array}{l}c, v(1), \Delta y(3), \\
\Delta p(3), \Delta m(3)\end{array}$ & .333 & $\begin{array}{l}\Delta \mathrm{m}(3) \\
\mathrm{v}(1)\end{array}$ & $\begin{array}{ll}4.02 & (.011) \\
3.37 & (.070)\end{array}$ \\
\hline 3. & $\Delta \mathrm{p}$ & $\begin{array}{l}c, v(1), \Delta y(3), \\
\Delta p(3), \Delta m(3)\end{array}$ & .562 & $\begin{array}{r}\Delta m(3) \\
v(1)\end{array}$ & $\begin{array}{rr}.92 & (.434) \\
5.42 & (.023)\end{array}$ \\
\hline 4. & $\Delta \mathrm{m}$ & $\begin{array}{l}c, v(1), \Delta y(3), \\
\Delta p(3), \Delta m(3) \\
\Delta r(3)\end{array}$ & .563 & $\Delta r(3)$ & $1.16(.332)$ \\
\hline 5. & $\Delta y$ & $\begin{array}{l}\mathrm{c}, \mathrm{y}(1), \Delta \mathrm{y}(3) \\
\Delta \mathrm{p}(3), \Delta \mathrm{m}(3) \\
\Delta \mathrm{r}(3)\end{array}$ & .322 & $\Delta r(3)$ & $.62(.605)$ \\
\hline 6. & $\Delta \mathrm{p}$ & $\begin{array}{l}\mathrm{c}, v(1), \Delta y(3), \\
\Delta \mathrm{p}(3), \Delta \mathrm{m}(3) \\
\Delta \mathrm{x}(3)\end{array}$ & .554 & $\Delta \mathrm{r}(3)$ & $.55(.650)$ \\
\hline 7. & $\Delta m$ & $\begin{array}{l}c, v(1), \Delta y(3), \\
\Delta p(3), \Delta m(3) \\
\Delta s(3)\end{array}$ & .595 & $\Delta s(3)$ & $3.63(.017)$ \\
\hline 8. & $\Delta y$ & $\begin{array}{l}c, v(1), \Delta y(3) \\
\Delta p(3), \Delta \mathrm{m}(3) \\
\Delta s(3)\end{array}$ & .348 & $\Delta s(3)$ & $2.56(.206)$ \\
\hline 9. & $\Delta \mathrm{p}$ & $\begin{array}{l}\mathrm{c}, \mathrm{v}(1), \Delta \mathrm{y}(3) \\
\Delta \mathrm{p}(3), \Delta \mathrm{m}(3) \\
\Delta \mathrm{s}(3)\end{array}$ & .589 & $\Delta s(3)$ & $2.59(.060)$ \\
\hline 10. & $\Delta s$ & $\begin{array}{l}c, v(1), \Delta y(3), \\
\Delta p(3), \Delta m(3) \\
\Delta s(3)\end{array}$ & .160 & $\begin{array}{r}\Delta y(3) \\
\Delta p(3) \\
\Delta m(3) \\
v(1)\end{array}$ & $\begin{array}{ll}1.39 & (.253) \\
3.76 & (.015) \\
2.70 & (.052) \\
1.42 & (.237)\end{array}$ \\
\hline
\end{tabular}


Note: $c$ is a constant, $v=m-p-y$, and $r$ is the rate of interest. For regressors and excluded variable(s), the number in brackets represents the number of lagged values of the indicated variable. See Appendix I for sources of data.

Table 2 - Performance Measures for Different simulated Models

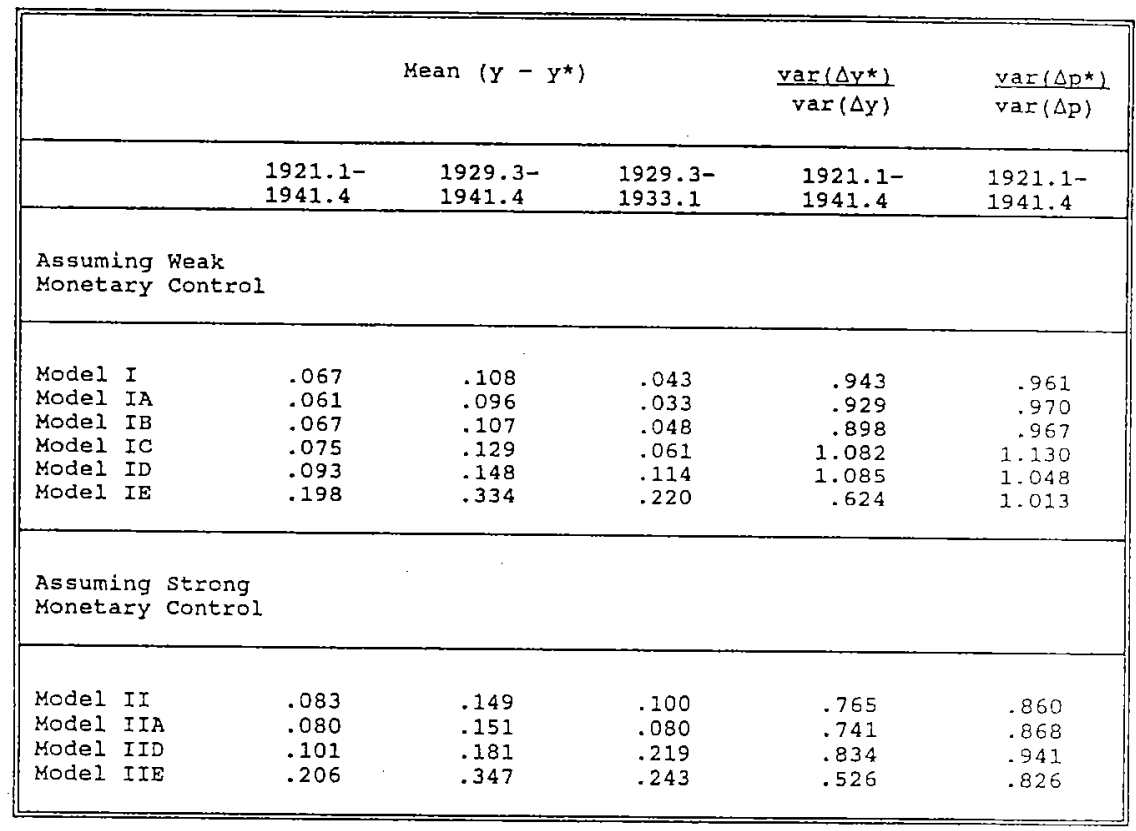

Note: A star (*) indicates simulated value. Models I and II represent the basic 3-variable version; IA and IIA exclude $v ;$ IB and IC include $s$ and I, respectively; ID and IID use data on industrial production and WPI (ingtead of the Balke-Gordon series on real GNP and the GNP deflator). and IE and IIE estimate parameters on the basis of 1921.1-1929.4 data. see text for further explanations of these models. 
Notes:

* This project is financed by a grant from the Harry and Lynde Bradley Foundation. The authors thank the Foundation for its support. For helpful comments and suggestions we thank Ben Bernanke, Steve Cecchetti, Charles Evans, Bennett McCallum, Bob Rasche, Pierre Siklog, Jim stock, Paul wachtel and participants at the Rutgers Mini-Conference on the Great Depression, February 1993 and the NBER Macro History Conference, April 1993. For able research assistance we thank Jakob Koenes.

ENDNOTES

1. See also Feldstein and stock (1992) who simulate the effect of an optimal monetary policy rule on nominal GDP over the 1959-92 period.

2. In this exercise we do not consider the interesting questions as to whether the Fed could have followed a constant money growth rate given its understanding of monetary policy and given its commitment to the gold standard.

A considerable debate has raged over whether the Fed followed a successful countercyclical policy in the 1920's from which it departed after Benjamin Strong's death in 1928 (Friedman and Schwartz, 1963), or whether it continued to follow the flawed Burgess-Riefler-strong doctrine of focussing on the levels of member bank borrowing and short-term nominal interest rates as policy indicators (Wicker, 1965, Brunner and Meltzer, 1968). According to the latier view the Fed conducted expansionary open market operations in the recessions of 1924 and 1927 because the mildness of the contraction did not allow member bank indebtedness to fall nor nominal interest rates to decline. By contrast in 1930 the severity of the depression and widespread bank failures reduced member bank borrowing; also deflationary expectations reduced nominal interest rates. The Fed did not act because it did not feel action was warranted (see wheelock 1992 and Bordo 1989). If this interpretation is correct the fed may not have had the requisite understanding to maintain stable money. 
others have argued that as long as the U.S. was committed to gold convertibility, the fed could not have undertaken sufficient expansion of domestic credit to maintain stable money through the Great Depression (Eichengreen 1992). Successful expansionary policy in 1924 and 1927 , according to this view, only occurred because it was consistent with international objectiveg (wicker 1965). In the early 1930's concern over the level of free gold prevented the Fed, even if it had the underatanding, from following an expansionary policy that would lead to significant gold outflows.

3. We use the Balke-Gordon (1986) data based on the Kuznets-Commerce sources. Romer (1988) hag criticized this data set and constructed her own series. Her data considerably reduce the severity of the 1923-24, 1926-27, and 1937-38 recessions but not that of the Great contraction of 1929-33.

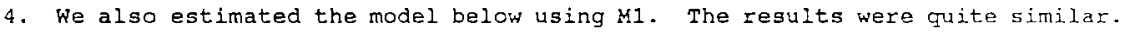
5. Romer (1990) attributes the decline in output 1929-30 to the effects of the stock market crash not the decline in the money stock.

6. Temin (1978) disputed Friedman and Schwartz's contention that banking panics were the cause of the collapse in the money supply. His regressions showed that the banking failures of the $1930^{\prime}$ s entirely reflected the decline in economic activity. A number of subsequent papers refuted this finding (Anderson and Butkiewicz 1980, Wicker, 1980, Mayer, 1978, Boughton and wicker 1979).

7. McCallum (1990) uses this measure. Bernanke (1983) uses the real value of suspended bank deposits as a proxy for the nonmonetary influence of the banking failures on economic activity.

8. According to white (1984), however, the majority of banks that failed after 1930 had characteristics similar to those that failed in the 1920 s.

9. See, for example, Blanchard (1990).

10. For each of these variables, the augmented Dickey-Fuller test (both with and without a time trend) does not reject the hypothesis that the variable contains a unit root. 
11. See Lucas (1988) who argues that the long-run U.S. money demand is stable. Algo see Hafer and Jansen (1991) for evidence supporting a cointegrating money demand relation for $M 2$ over the period from 1915 to 1988 . For a contrary view, see McCallum (1993) who argues that shocks to the money demand function are likely to include permanent stochastic changes in the technology for affecting transactions.

12. In the case where $z_{1}=s_{1}, \mathbf{g}$ is included in (2) and (3) for reasons discussed by Bernanke (1983).

13. Existing evidence, for example, Lucas (1988), and hoffman and Ragche (1991) suggesto that the income elasticity of money demand is close to one. The assumption that $\alpha_{2}=0$ is relaxed later in simulations based on the extended model that includes the interest rate. Note that $\alpha_{0}$ the intercept in the demand for money) is left out and is included in the constant terms of the regressions. 14. Four lags for each variable were also tried but the additional lagged terms were not significant.

15. It might be argued that at the onset of the Great contraction, the Fed would not have known the average interwar money growth rate and thus, it may be more appropriate to set $\theta$ equal to some rate reflecting the 1920 's experience. The average value of $\Delta m$ for 1921-29 is, in fact, greater than the interwar average. As discussed above, however, we eschew using a higher rate of money growth in the present simulations on the grounds that the estimated parameters of our model are likely to reflect the average inflationary experience of the whole interwar period. In the next section, we do set $\theta$ equal to the average An value for 1921.1-1929.4 in an alternative simulation based on a model estimated for the same period.

16. In model IC, $v$ is measured as $m-p-y-\alpha_{2} r$ with $\alpha_{2}=-.04$. This estimate of $\alpha_{2}$ was derived by applying the dynamic ols procedure in stock and watson 
(1989) to the money demand relation (1), constraining $\alpha_{1}$ equal to one and using four leads and lagg.

17. Nominal income growth was regressed on a constant, the lagged value of $v, 3$ lagged values of $\Delta m$ and 3 of its own lagged valueg. Mccallum's (1990) nominalincone equation is slightly different (it includes only one lagged value of $\Delta \mathrm{m}$ and no error-correction term) but this equation also breaks in 1933.2 according to the chow test. However, as Mccallum notes, a break at this date is not indicated if two dumm variables for the 1930.2 and 1930.3 quarters are also included in the equation. 
Andergon, B. and J. Butkiewicz (1980). "Money, spending, and the Great Depression?" Southern Economic Journal, 47: 388-403.

Balke, N.S. and R.J. Gordon (1986). "Historical Data" in R. Gordon (ed.), The American Business Cycle: Continuity and Change. Chicago: University of Chicago Press, pp. 781-850.

Bernanke, B. and M. Gertler (1989). "Agency Costs, Net Forth and Business Fluctuations," American Economic Review, 79: 14-31.

Bernanke, 8. and M. Gertler (1990). "Financial Fragility and Economic Performance," Quarterly Journal of Economicg, 105 (February): 87-114.

Bernanke, B. (1983). "Nonmonetary Effects of the Financial Crisis in the Propagation of the Great Depression." American Economic Review, 73: $257-76$.

Blanchard, 0. (1990). "Why Does Money Affect Output? A Sumary." Chap. 15 in B. M. Friedman and F. H. Mahn (eds.), Handbook of Monetary Economics, Vol. 2, Ansterdam: North Holland Publishers.

Bordo, M. D. (1989). "The Contribution of A Monetary History of the United States, 1867-1960 to Monetary History," in M.D. Bordo (ed.) Money, Historye and International Einance: Essays in Honor of Anna 3 . Schwartz. Chicago: University of Chicago Press.

Boughton, J.M. and E.R. Wicker (1979). "The Behavior of the Currency-Deposit Ratio during the Great Depression." Journal of Money, Credit and Banking, 11: 405-18.

Brunner, K. and A.H. Meltzer (1968). "What Did We Learn from the Monetary Experience of the United states in the Great Depression?" Canadian Journal of Economics, 1: $336-48$.

Cecchetti, S. G. (1992). "Prices During the Great Depression: Was the Deflation of 1930-1932 Really Anticipated?" American Economic Review, $82: 141-56$. 
Cecchetti, S. G. and G. Karras (1992). "sources of Output Fluctuations During the Interwar Period: Further Evidence on the Causes of the Great Depression." NBER Working Paper No. 4049, April.

Eichenbaum, M. (1992). "Comment on 'Central Bank Behavior and the Strategy of Monetary Policy: Observations from six Industrialized Countries' by Ben Bernanke and Frederic Mishkin." In NBER Macroeconomics Annual 1992, ed. by 0 . Blanchard and S. Fisher, p. 233.

Eichengreen, B. (1992). Golden Fetters: The Gold Standard and the Great Depression, 1929-1939. New York: Oxford University Press.

Evans, $H$. and Wachtel, P. (1991). "The Fisher Effect in the Great Depression." Stern School, New York University (mimeo).

Feldstein, M. and J. Stock. (1992). "The Use of a Monetary Aggregate to Target Nominal GDP." Harvard University mimeo. Decenber.

Field, A. J. (1984). "Asset Exchanges and the Tzansaction Demand for Money, 1919-1929." American. Economic_Review, 74: 43-59.

Fisher, I. (1933). "The Debt-Deflation Theory of Great Depressions." Econometrica, 3: 339-57.

Friedman, H. (1960). A Program for Monetary Stability. New York: Fordham University Press.

Friedman, M. and A.J. Schwartz (1963). A Monetary History of the United States. Princeton: Princeton University Press.

Friedman, M. and A.J. Schwartz. (1970). Monetary Statistics of the United States. New York: Columbia University Press for NBER.

Hafer, R.W. and D.W. Jansen (1991). "The Demand for Koney in the united States: Evidence from cointegrating Tests". Journal of Money, Credit and Banking, 23: 155-168.

Hamilton, J.D. (1987). "Monetary Factors in the Great Depression." Iournal of Monetary Economics, 19: 145-70.

Hamilton, J.D. (1992). "Was the Deflation During the Great Depression Anticipated? Evidence from the Commodity Futures Market." American Economic Reyiew, $82: 157-78$. 
Hoffman, D. and R.H. Rasche (1991). "Long-Run Income and Interegt

Elasticities of Money Demand in the United States." Review of Economics and Statisticg, $53: 665-74$.

Lucas, R.E., Jr. (1976). "Economic Policy Evaluation: A Critigue." In Carneqie-Rochester Conference Serieg on Public policy, Karl Brunner and Allan H. Meltzer (edg.), Amsterdam: North-Holland. Vol. 1, 19-46. Lucas, R.E., Jr. (1988). "Money Demand in the United states: A Quantitative Review," in Karl Brunner and Allan H. Meltzer (eds.), Carnegie-Rochester Conference Series on Public Policy, 29: 137-68.

Mccallum, B.T. (1990). "Could a Monetary Bage Rule have Prevented the Great Depression?" Journal of Monetary Economics, 26 (No. 1): 3-26.

McCaluum, B.T. (1993). "Unit Roots in Macro-economic Time series: some Critical issues" Federal Reserve Bank of Richmond Quarterly, 79 (No.2): $13-44$

Mayer, T. (1978). "Money and the Great Depression: Some Reflections on Temin's Recent Book." Explarations in Economic Kistory, 14: 127-45.

Modigliani, F. (1969). "Some Empirical Facts of Monetary Management and Rules Versus Discretion." Journal of Political Economy, 72: 211-45,

Nelson, D.B. (1992). "Was the Deflation of 1929-30 Anticipated? The Monetary Regime as Viewed by the Business Press." Research in Economic History, $13: 1-66$.

Romer, C.D. (1988). "World War I and the Postwar Depression: A

Reinterpretation Based on Alternative Estimates of GNP." Journal of Monetary Economicg 22: $91-115$.

Romer, C.D. (1990). "The Great Crash and the Onset of the Great Depression." Quarterly Journal of Economics, 105: 597-624.

Romer, C.D. (1992). "What Ended the Great Depression?" Journal of Economic History, vol. 52 , No. 4, 757-84.

Solow, R. (1956). "A Contribution to the Theory of Economic Growth." Quarterly Journal of Economics, $70(1): 65-94$. 
Stock, J.H. and M.W. Matson (1989). "A Simple MIE of cointegrating Vectors in General Integrated Systems." NEER Technical Horking Paper No. 83. Temin, P. (1978). Did Monetary Factors Cause the Great Depression? New York: Norton.

Temin, P. (1989). Lessons from the Great Depression. Cambridge: MIT Press.

U.S. Department of Commerce. (1973). Long-Term Economic Growth, 1860-1970. Washington, D.C.: U.S. Government Printing office.

Warburton, c. (1966). "Monetary Theory, Full Production, and the Great Depression." Ch. 5, in Depression, Inflation, and Monetary Policy. Baltimore: Johns Hopkins University Press.

Wheelock, D. (1992). "Monetary Policy in the Great Depression: What the Fed Did and why." Federal Reserve Bank of St. Louig Review, Vol. 74, No. 2 : $3-28$.

White, E.N. (1984). "A Reinterpretation of the Banking Crisis of 1930." Journal of Economic History, 44, No. 1, 119-38.

Wicker, E. (1965). "Federal Reserve Monetary Policy, 1922-33: A Reinterpretation." Journal of Political Economy, 73: 325-43.

Wicker, E. R. (1980). "R Reconstruction of the Causes of the Banking Fanic of 1930." Journal of Economic History, 40: 571-83. 


\section{Quarterly Data}

Real Gross National Product and Gross National Product Implicit Price Deflator: Balke-Gordon (1986), Table 2 .

Suspended Bank Deposits: Federal Reserve Bulletin, Sept. 1937, p. 909; McCallum (1990).

Money stock (H2): Friedman and Schwartz (1970), Table 2, pp. 61-73.

Monetary Base: Friedman and Schwartz (1963), Appendix B, Table B-3, pp. 799808.

Interest Rate: Commercial paper rate in Balke-Gordon (1986), Table 2.

\section{Monthly Data}

Consumer Price Index: 1910-40, NBER Business Cycle Series no. 04072; 1941-61, NBER Business Cycle Series no. 04052 .

Industral Production: 1919-56, NBER Business Cycle series no. 01303.

Money Stock (M2): Friedman and Schwartz (1970), Table 1, pp. 8-52. 